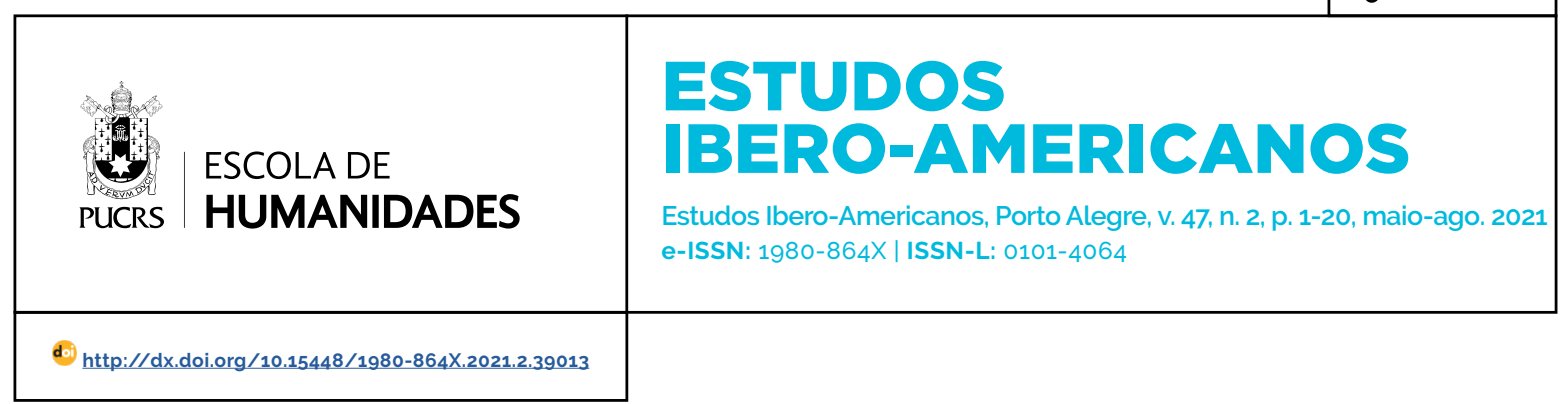

DOSSIÊ: HISTÓRIA PÚBLICA NA AMÉRICA LATINA: MEDIAÇÕES DO PASSADO, DEMANDAS SOCIAIS E TEMPO PRESENTE

\title{
História Pública, História em Quarentena e Ditadura
}

\author{
Public History, History in Quarantine and Dictatorship \\ Historia Pública. Historia en Cuarentena y Dictadura
}

\section{Antonio Mauricio \\ Freitas Brito ${ }^{1}$ \\ orcid.org/0000-0002-7570-1632 \\ mafbrito@hotmail.com}

\author{
Iracélli da Cruz Alves ${ }^{2}$ \\ orcid.org/0000-0003-0331-4913 \\ iracelli_alves@yahoo.com.br
}

\section{Rafael Rosa da Rocha ${ }^{3}$}

orcid.org/0000-0002-4849-7111 rafaelrosa.historia@gmail.com

Recebido em: 30 ago. 2020. Aprovado em: 26 mar. 2021. Publicado em: 31 ago. 2021.
Resumo: Este artigo explora o acervo do projeto "História em Quarentena". Praticada durante a pandemia da COVID-19 como parte do repertório da história pública, a experiência difundida on-line deixou um legado de aproximadamente 150 horas de material gravado disponivel no Facebook e Youtube. O conteúdo produzido evidencia o potencial do projeto para a pesquisa histórica, além do diálogo com questões socialmente vivas. Com base nesta lógica, selecionamos como material de análise os videos sobre os "Mitos da ditadura" no Brasil. A abordagem consistiu na sistematização de 20 "mitos" debatidos. Ademais, sugerimos uma agenda de pesquisa sobre a ditadura suscitada pelas discussões. O projeto "História em Quarentena" é um laboratório para reflexão sobre possibilidades e dilemas da divulgação científica e sua conexão com a história pública.

Palavras-chave: História pública. Ditadura. Historiografia. História em Quarentena.

Abstract: This article explores the collection of the History in Quarantine Project. Practiced during the Covid-19 pandemic as part of the Public History repertoire, the experience disseminated online left a legacy of approximately 150 hours of recorded material made available on Facebook and Youtube. The content produced shows the potential of the project for historical research, in addition to the dialogue with socially alive issues. Based on this logic, we selected as analysis material the videos about the "Myths of the Dictatorship" in Brazil. The approach consisted of systematizing 20 "myths" discussed. In addition, we suggest a research agenda on the dictatorship raised by the discussions. The History in Quarantine Project is a laboratory for reflection on the possibilities and dilemmas of scientific dissemination and its connection with Public History.

Keywords: Public history. Dictatorship. Historiography. History in Quarantine.

Resumen: Este artículo explora la colección del proyecto Historia en Cuarentena. Practicada durante la pandemia Covid-19 como parte del repertorio de Historia Pública, la experiencia difundida en línea dejó un legado de aproximadamente 150 horas de material grabado disponible en Facebook y Youtube. El contenido producido muestra el potencial del proyecto para la investigación histórica, además del diálogo con temas socialmente vivos. Con base en esta lógica, seleccionamos como material de análisis los videos acerca de los "Mitos de la Dictadura" en Brasil. El Proyecto Historia en Cuarentena es un laboratorio de reflexión sobre las posibilidades y dilemas de la divulgación científica y su conexión con la Historia Pública.

Palabras clave: Historia pública. Dictadura. Historiografía. Historia en Cuarentena. 


\section{Introdução}

Durante a pandemia da COVID-19, diversas ações foram construidas nas redes sociais para lidar com a quarentena. Exemplo instigante da capacidade de auto-organização de setores civis através das vias digitais, a live passou a fazer parte da gramática de largos segmentos. No Brasil, grupos acadêmicos não perderam a oportunidade de veicular suas percepções através da rede, tampouco as historiadoras e historiadores - profissionais preocupados com a experiência humana no tempo. A Associação Nacional de História (ANPUH) viabilizou eventos discutindo temas como Regulamentação da Profissão do Historiador e Negacionismo. Vários Grupos de Trabalho (GTs) - História Política, História da África, Emancipações e Pós-abolição, Mundos do Trabalho, Relações Internacionais, dentre outros - organizaram atividades. Historiadoras negras e historiadores negros também desenvolveram ações através da página @Historiadorxsnegrxs no Instagram. Mesmo sem um levantamento sistemático, é possivel dizer que houve um sem-número de pesquisadoras e pesquisadores palestrando, comentando e debatendo pela internet.

Com pioneirismo e capacidade de continuidade desde o início da pandemia, o projeto "História em Quarentena", doravante designado $\mathrm{HQ}$, estreou em 23 de março de 2020 e destacou-se na temporada de ocupações no mundo virtual. Idealizado pelos historiadores Paulo Gomes e Carlos Chaplin, no processo novos nomes foram sendo incorporados. Ao final, além dos idealizadores, o HQ contou com a coordenação das historiadoras Natália Guerellus, Mariana Meneses, Mélanie Toulhoat e Lucas Pedretti. Pensado para ser desenvolvido durante os "tempos pandemônicos" - na definição figurativa do próprio $\mathrm{HQ}$ - dado a expectativa de que a pandemia não iria demorar, o projeto foi encerrado na sua $20 .^{\text {a }}$ semana, deixando um legado de quase 150 horas de material gravado sobre diversos temas e períodos: história das doenças, história moderna, história contemporânea, atualidade. No momento de escrita deste texto, todo material encontrava-se disponibilizado nas páginas do YouTube ${ }^{4}$ e do Facebook ${ }^{5}$. O conteúdo foi editado também na modalidade podcast.

Durante a temporada, o HQ manteve-se regular, movimentando uma programação semanal, sem interrupção. $O$ encerramento foi planejado e marcado por um esforço de autoavaliação em que os coordenadores discorreram sobre as motivações iniciais e o balanço da experiência. Além da regularidade, houve uma preocupação com a recepção, vide um questionário feito visando mapear o perfil da audiência. O projeto ganha relevância ainda por ter reunido cerca de 160 profissionais. A maioria foi composta de historiadoras e historiadores, mas houve também artistas, jornalistas, advogados, sociólogos, ativistas, cientistas politicos, incorporando a preocupação de dialogar com outras vozes a respeito do passado-presente. Diversos temas foram explorados em 105 videos: 52 debates, 45 lives e 8 entrevistas, que oscilam individualmente entre 50 minutos e quase 3 horas de duração.

Estes elementos sugerem que o HQ é um exemplo de um tipo de história pública que merece ser investigado pela sua dimensão de prática autorreconhecida pelos organizadores. Com um instigante título em sintonia com o contexto da pandemia, o projeto começou com lives e, aos poucos, segundo o grupo que o organizou, foi se ajustando para incorporar mais o formato dos debates e entrevistas em um tom de conversa mais fluente e dinâmica. $O$ $H Q$ combinou ótima qualidade técnica do design de apresentação dos videos com um ativismo prático sem investimento técnico, exceto na transmissão, no armazenamento no site do projeto e na edição em formato de podcast. De acordo com a equipe organizadora, não houve um planejamento de longo prazo na implementação do projeto. A reflexão/ ação ocorreu no calor da experiência e do "caos" da vida imersa na pandemia.

Além do autorreconhecimento e dos argumentos já elencados, o projeto pode ser reconhecido como vinculado à história pública pela atuação prática e pela "reflexão" a respeito da prática (SAN-

4 Disponivel em: https://www.youtube.com/channel/UCgYcNDc_HB7VPLLwDG1T4Sw/videos. Acesso em: 29 ago. 2020. A análise do conteúdo dos vídeos foi desenvolvida a partir do acervo do $\mathrm{HQ}$ disponibilizado nesta plataforma.

5 Perfil Facebook História em Quarentena. Disponivel em: https://www.facebook.com/historiaemquarentena. Acesso em: 29 ago. 2020. 
THIAGO, 2016, p. 25). Neste sentido, este texto pretende contribuir com reflexões sobre o projeto indicando algumas das suas contribuições para a historiografia sobre a ditadura no Brasil. Consideramos o HQ enquanto um laboratório rico de aprendizagens em meio ao boom recente de ocupação das redes sociais por historiadoras e historiadores. Pensar o projeto nos remete também às questões relacionadas aos dilemas, às possibilidades e aos desafios da história pública no Brasil.

\section{$1 \mathrm{HQ}$ : divulgação científica e história para o público}

Ricardo Santhiago (2016, p. 28) delineou a história pública como uma área de estudo e de ação com quatro engajamentos fundamentais, que podem aparecer imbricados: a história feita para o público, em que a audiência torna-se central; a história com o público, que seria uma história colaborativa, na qual a ideia de "autoridade compartilhada" é essencial; a história feita pelo público, que se preocupa em incorporar formas não institucionais de história e memória; e a história e público, que abrangeria a reflexividade e a autorreflexividade do campo.

A partir dessa tipologia, o HQ pode ser caracterizado como uma história para o público através da internet. No processo, houve interações com e entre o público. ${ }^{6}$ Elas aconteciam, especialmente, nos chats e por meio de comentários durante as atividades, mas a autoridade centrava-se nos/nas "palestrantes", que ocupavam lugar central na tela como divulgadores do conhecimento histórico. 0 HQ é uma experiência que se aproxima do que foi sintetizado como o "emprego de historiadores e do método histórico fora da academia" (KELLEY, 1978, p. 16) - no caso, falando além dos muros físicose divulgando o conhecimento histórico. As atividades pautaram questões socialmente controversas na arena pública, além de compartilharem a reflexão acadêmica sobre o papel da história através de um meio digital com potencial tecnológico para ser acessado por um público mais amplo do que um corpo de especialistas. Segundo um dos organizadores, o público desenvolveu algum papel nos rumos do projeto, especialmente em apresentar a demanda para o $\mathrm{HQ}$ incorporar a dimensão da representatividade de raça, gênero e região na composição das mesas virtuais. ${ }^{7}$ Ainda que em pequena escala, neste exemplo, o HQ se aproxima de uma história com o público.

A forma como o projeto se estruturou leva à interrogação: quais públicos o HQ conseguiu atingir durante as transmissões na quarentena? É uma pergunta difícil de responder dada a complexidade da dinâmica das redes sociais. O próprio grupo que coordenou o projeto levantou o questionamento, refletindo sobre em que medida o projeto "furou a bolha". No exercício de autorreflexão, a equipe elaborou um questionário tentando mapear a recepção e o perfil da sua audiência. Embora os dados sejam incipientes para amostragem em razão do baixo número de respostas, provavelmente o alcance maior ocorreu entre o público acadêmico. Quase noventa por cento das pessoas que responderam afirmaram ser graduandos e/ou pós-graduandos, sendo 32\% de graduação e 56\% de pós. Dessas, todas são brasileiras de todas as regiões do Brasil, a maioria branca (54.3\%), homem $(50,6 \%)$ e na faixa etária entre os 25 e 40 anos (47\%). ${ }^{8}$

No quesito técnico, como já mencionado, as atividades não sofreram intervenções profissionalizadas, mesmo aquelas caracterizadas por

\footnotetext{
6 Parece promissor investigar a página do projeto HQ no Facebook, bem como as interações desenvolvidas entre o público, pois o alcance de visualizações foi bem mais amplo por lá. Tomemos o exemplo das duas entrevistas desenvolvidas na série "Mitos da ditadura". Em 24 de março de 2021, a entrevista com Carlos Fico registrava 3,4 mil visualizações, 74 curtidas e 11 comentários no Facebook, enquanto o YouTube indicava 320 visualizações, 03 comentários, 43 curtidas e duas não curtidas. A entrevista com Rodrigo Patto e Marcos Napolitano contava com 3.5 mil visualizações no Facebook, 113 curtidas e 56 comentários (interações da mediação do HQ com o público, perguntas para os entrevistados, comentários do público em sintonia com o que era dito nas entrevistas etc.). Já no YouTube, houve 242 visualizações e nenhum comentário nem (des)curtida. Portanto, o Facebook é a plataforma mais adequada para mapear as interações da mediação do $\mathrm{HQ}$ com o público, perguntas para os entrevistados, comentários do público em sintonia com o que era dito nas entrevistas etc.

7 Afirmação presente na abertura do debate intitulado "Mitos da ditadura: estudantes, imprensa e mulheres", ocorrido na 18. ${ }^{a}$ semana do projeto. Disponivel em: https://www.youtube.com/watch?v=Nn7W7-LRN34\&List=PLwU3JeT5boUcPPU64_aiWh5r7qVLNXctU\&index=21 (02'30"). Acesso em: 29 ago. 2020.

8 A conversa de balanço - intitulada "E a pandemia não acabou: encerramento do projeto História em Quarentenal Debate" - aconteceu no dia 8 de agosto de 2020. Na época, segundo informações da própria equipe organizadora, o HQ contava com 16 mil seguidores no Facebook, mas somente 80 pessoas tinham respondido o questionário até aquele momento. Disponivel em: https://www.youtube.com/ watch?v=M5C3FsCxvH4\&t=1278s. Acesso em: 29 ago. 2020.
} 
problemas de conexão. A metodologia foi crua: transmissão, gravação e disponibilização. Ou seja, não houve edição, cortes, tampouco inserção de nenhuma natureza na disponibilização do conteúdo das atividades. Não houve intenção de didática, entretenimento, tampouco preocupação com uma linguagem legivel para não especializados e iniciados no mundo acadêmico e nos temas em particular. $O$ formato das atividades falas, estilo, palestra sem edição -, a duração e a divulgação pelo Facebook e pelo Instagram sem maior investimento, fortalecem a hipótese de que o público que acompanhou algumas atividades do $H Q$ foi majoritariamente de acadêmicos ou pessoas com formação e interesses especíicos na História, além de amigos, familiares e pessoas próximas dos convidados assistindo à atividade com graus diversos de foco e preocupações.

Sem esquecer que o Brasil ainda é atravessado pela exclusão digital, a priori, o HQ possibilitou condições para um público acompanhar os debates em tempo real ou a posteriori, já que o material ficou gravado. Ainda que seja possivel interrogar em que medida a forma adotada foi capaz de atrair um público amplo, a iniciativa traduz o que foi dito por Mauad, Almeida e Santhiago (2016, p. 12) a respeito da história pública: "de fato a produção de materiais para circulação e consumo de uma audiência mais ampla do que nossos pares acadêmicos consiste em uma de suas modalidades mais nobres".

Falando de nobreza e generosidade, no que diz respeito à historiografia sobre a ditadura, o projeto $\mathrm{HQ}$ oportunizou reunir autoras e autores que são referências bibliográficas imprescindiveis nos seus temas. A maioria dos pesquisadores parece ser do Sudeste, sendo que em alguns casos houve mesas com pessoas de diferentes regiões do País, que talvez poucos fora do eixo Rio-São Paulo tivessem a oportunidade de assistir presencialmente - exceto em eventos nacionais como os Encontros da ANPUH cujo acesso necessariamente é restrito pelo valor das taxas de inscrição, pelo deslocamento, pelo tempo exigido pela duração do evento e a infraestrutura necessária para viabilizar a presença - local de estadia, alimentação, mobilidade e lazer.

Para além do debate sobre quem realmente acompanhou, o projeto é um testemunho que permite acessar algumas percepções dos historiadores a respeito do presente, da pandemia e das projeções de futuro. Neste quesito, o HQ pode ser pensado como um exemplo de História Imediata pela "proximidade temporal [...] em relação ao tema tratado e proximidade material [...] em relação à crise estudada" (LACOUTURE, 1978, p. 216). Além disso, é uma experiência no curso do tempo presente sem desfecho, pois "não está instruido pelo futuro" (CHAUEVAU; TÉTART, 1999, p. 26), já que a pandemia continuou após o projeto e permanece enquanto este texto é concluido. Mostrando o "parentesco radical" (SHOPES, 2014 apud ALMEIDA, 2016, p. 17) entre história pública e História Oral, o acervo do HQ se aproxima potencialmente dos "arquivos futuros": um registro de vozes que poderá vir a ser utilizado para compreender os meses iniciais daquela temporalidade.

Além do tempo da pandemia, o acervo é um guia para o debate sobre inúmeros objetos. Dentre os diversos assuntos abordados, priorizamos a ditadura (civil) militar' - tema que, isoladamente, mais ocupou a atenção do $\mathrm{HQ}$. Além disso, em um contexto de disputas públicas a respeito da ditadura combinada com uma apologia da violência do Terrorismo de Estado por alguns grupos, estudar e dialogar sobre o periodo têm relevância, já que se trata de uma demanda social mobilizada por diversos sujeitos que constroem narrativas de diferentes lugares.

Para a análise do vasto material, apresentamos uma sintese de questões presentes nos debates, lives e entrevistas. Priorizamos os sete videos sobre os "Mitos da ditadura", bem como o debate de avaliação ocorrido entre os organizadores do projeto. Feito isso, ensaiamos uma sintese dos "mitos" e algumas reflexões sobre a historiografia em torno da ditadura. Além de sistematizar o que foi dito, nos interessa

9 Uma das controvérsias historiográficas sobre o periodo diz respeito à terminologia mais adequada para expressar a natureza da ditadura e o papel dos sujeitos na sua configuração. O parêntese acolhe duas diferentes possibilidades historiográficas de nomear e compreender a ditadura. Além de ditadura militar ou ditadura civil-militar, existem outras semânticas como ditadura empresarial-militar, ditadura hetero-militar, regime militar e regime ditatorial-militar - dentre outras. 
pensar os não ditos através da noção do arquivo como o "indício de uma falta" (ROUSSO, 1996). Em resumo, exploramos o HQ como demonstração de presença, mas também a partir de ausências, interrogações e possibilidades para a pesquisa e a reflexão sobre história pública e ditadura.

\section{Os "Mitos da ditadura" no HQ: desafios e possibilidades historiográficas}

A série "Mitos da ditadura" ocorreu na décima oitava e décima nona semana do projeto e contou com duas entrevistas e cinco debates..$^{10}$ Os encontros contribuiram para divulgar os exageros/ deformações/simplificações/falseamentos relacionados ao período, além de elencar algumas controvérsias que têm envolvido a pesquisa acadêmica e o debate público sobre a ditadura no tempo presente. A partir das exposições, sintetizamos em uma tabela alguns argumentos relacionados a vinte (20) "mitos".

Houve pouca reflexão sobre a noção de "mito". Ele foi pensado muitas vezes como falseamento da realidade, havendo rara problematização. Grosso modo, ao contrário do que prevaleceu nas discussões, as mitologias têm "sua lógica e coerência próprias, não sendo simples invenção ou engodo" (BORGES, 2003, p. 12). Mas houve exceção. Rodri- go Patto Sá Motta, por exemplo, ressaltou que o debate não deve partir da oposição simples entre mito como fábula e história como a "verdade verdadeira". As narrativas mitológicas, ainda segundo o historiador, carregam elementos de verossimilhança e precisam de tais elementos para que tenham alguma eficácia e duração no tempo. Para Motta, isso não invalida a necessidade de questioná-las a partir da mobilização da racionalidade histórica consubstanciada no uso de fontes e método. ${ }^{11}$

A série oferece ferramentas de reflexão sobre como as pesquisadoras e os pesquisadores pensam o seu papel em um debate público que extrapole o falar exclusivamente para os pares. A tabela foi construida tomando como ponto de partida a forma como as perguntas foram estruturadas pelo HQ. Inicialmente, solicitava-se uma apresentação dos mitos relacionados à área de pesquisa do convidado ou da convidada; depois interrogava-se sobre as descobertas que desconstroem os mitos; por fim, pedia-se um comentário sobre o papel do intelectual no debate público mais amplo sobre a ditadura. Na Tabela 1 , apresentaremos apenas alguns dos dois primeiros elementos, já que na última pergunta as falas se repetiram no sentido de evidenciar a importância de enfrentarmos os negacionismos ${ }^{12}$ através das pesquisas históricas e do debate público. ${ }^{13}$

\footnotetext{
10 Entrevistas: 1. "Mitos da ditadura - usos políticos do passado", com Carlos Fico (UFRJ) (20/07/2020, 58'37"); 2. "Mitos da ditadura - usos políticos do passado II", com Marcos Napolitano (USP) e Rodrigo Patto Sá Motta (UFMG), (30/07/2020, 2h20'05"). Debates: 1. "Mitos da ditadura: estudantes, imprensa e mulheres" (22/07/2020, 1h15'36"), com Ana Rita Fonteles Duarte (UFCE), Angélica Muller (UFF) e Sônia Meneses (URCA); 2. "Mitos da ditadura: esquerda, militares e corrupção" (23/07/2020, 1h26'48"), com João Roberto Martins Filho (UFSCAR), Maria Paula Araújo (UFRJ) e Pedro Campos (UFFRJ); 3. "A ditadura para além do eixo Rio-São Paulo" (24/07/2020; 1h59'25"), com Alessandra Gasparotto (UFPel), Airton de Farias (IFCE), Pedro Fagundes Pedro Fagundes (UFES) e Thiago Broni (EAP/UFPA); 4 . "Mitos da ditadura: trabalhadores, LGBTs, luta armada, religiosos e negros" (25/07/2020,2h51'57"), com Alejandra Estevez (UFF), Caroline Cubas (Udesc), Flávia Rios (UFF), Kleber Simões (UNEB/UFBA) e Marcelo Ridenti (Unicamp); 5. "Mitos da ditadura: milagre econômico, futebol e propaganda" (26/07/2020, 1h37'36", com Paulo Robilloti (Unicamp), Livia Simões (UFF) e David Netto (UEM). Os links estão disponiveis na Tabela 1.

11 Ver a partir dos 21'25" da entrevista "Mitos da ditadura - usos políticos do passado II".

12 De acordo com Moraes (2011, p. 3), "o termo 'negacionismo' define ao mesmo tempo um campo político-intelectual internacionalmente articulado e uma prática. Por um lado, descreve uma variante propriamente 'Intelectual' de movimentos de extrema-direita do pós-Segunda Guerra Mundial, que busca por meio de textos produzidos na maior parte dos casos com aparência de historiografia, negar que o extermínio planejado e executado durante o Terceiro Reich tenha existido. Por outro lado, o termo diz respeito à própria prática de negação deste extermínio, desde aquela ligada a ação politica própria destes movimentos ou aquela dela derivada". A partir da reflexão sobre o Holocausto como "evento-matriz da questão do negacionismo", no Brasil, há uma compreensão da difusão do negacionismo para outros temas como a escravidão e a ditadura. "O negacionismo não tem como objetivo revisar e ampliar o conhecimento sobre o passado, mas destruir este conhecimento. As táticas são conhecidas: disseminação de falsidades e adulteração de fatos e processos históricos. O negacionismo é arma de determinados grupos politicos sectários" (NAPOLITANO; JUNQUEIRA, 2019, p. 2). A compreensão que permeou implicitamente os debates no HQ foi do negacionismo como "uma negação de bases factuais de processos históricos com vistas, sobretudo, a encobrir crimes e genocidios praticados pelos Estados" (NAPOLITANO, [2020]).

13 Convém destacar que a maioria dos mitos discutidos na série foi construção ideológica da ditadura, dos seus defensores e agentes repressivos. Há amplo consenso na historiografia acadêmica na crítica a essas construções mitológicas. Há outros mitos que, além de estarem no repertório oficial da ditadura e seus defensores, são incorporados pela memória de uma oposição liberal e estão presentes com algum tom na história acadêmica, a exemplo da acusação de que a esquerda era golpista. Há variantes e controvérsias a respeito do argumento presente na historiografia de que a esquerda não tinha compromisso com a democracia, ainda que não necessariamente os autores responsabilizem-na pelo golpe e pela ditadura. Há casos de autores que sublinham a retórica radicalizada da esquerda - o que gera controvérsias historiográficas a respeito de quem efetivamente deu o golpe. Noutro sentido, há mitos que foram construídos por sujeitos oposicionistas, a exemplo da construção pelo movimento estudantil da narrativa em torno de Edson Luís como mártir. E há, ainda, "mitos" que parecem ser lugares comuns difusos e tácitos que povoam um "senso comum acadêmico" e que são criticados.
} 
A forma como a maioria dos diálogos foi pensada nesta série do HQ, bem como sua sistematização em tabela talvez abra brecha para uma concepção de história pública que pensa as pesquisas acadêmicas como um "farol de luz mediante uma incompreensão do mundo" (SCHITTINO, 2016, p. 46), perspectiva que vem sendo questionada. Como propõe Michael Frisch (2016, p. 59), é fundamental a superação de uma ideia limitada e limitadora de história pública em que o historiador ou a historiadora seria aquela que tem o papel de produzir conteúdo, em contraposição ao público que seria o consumidor.

Na série "Mitos da ditadura", a impressão é que os historiadores e historiadoras foram direcionadas à tarefa de desenvolver a "consciência histórica". Novamente, o roteiro que predominou na atividade leva a essa interpretação. Frequentemente sequenciada em "mitos", seguida de uma pergunta a respeito do lugar dos historiadores no debate público para desconstruí-los, a estruturação talvez reforce um tipo de conexão entre história pública e uma história acadêmica iluminista.

Por outro lado, o HQ apresenta alguma ambiguidade na reflexão sobre a correlação entre história acadêmica e história pública. Isso porque, no momento de autoavaliação, a equipe que coordenou o projeto criticou o formato dos eventos acadêmicos, que seriam "chatos" e "encastelados". Embora o grupo reconheça a importância da história acadêmica, a história pública emerge nos relatos como uma alternativa para superar o problema do encastelamento, pois propicia que o conhecimento acadêmico seja acessado - e talvez mais bem-recebido - por um público mais amplo.

Partindo da reflexão do próprio grupo, em que medida a forma como o HQ foi montado radicalizou a crítica? Não sabemos se o questionário expressou a preocupação em saber como o público avaliou as atividades. Por outro lado, na prática, a história acadêmica pautou a agenda dos temas, os títulos das atividades, o perfil da maioria das pessoas convidadas e a dinâmica das atividades. Além do conteúdo e da atenção ao método, o formato do $\mathrm{HQ}$ foi modelado pelo universo acadêmico. Não por acaso, mesmo buscando um clima de descontração em tom de conversa, o tempo médio de duração das atividades é uma evidência de algo produzido em conexão com a tradição acadêmica. ${ }^{14}$

Nesta perspectiva, mesmo com eventuais ambiguidades na retórica dos organizadores, o HQ é uma experiência sugestiva de conexão entre história pública e história acadêmica. Ricardo Santhiago (2019. p. 149) analisa criticamente discursos e propostas nos EUA que "apresentam a história pública como uma variedade mais dinâmica, mais excitante, mais viçosa de história - quase como outra prática, isenta do bolor e da ferrugem da antiquada "história acadêmica". Sua interrogação afirma a sua perspectiva: "Não seria saudável, em vez de uma refundação epistemológica, a formação de um profissional e a constituição de uma cultura disciplinar permanentemente atenta à dimensão pública inescapável à sua atividade?" (SANTIGAGO, 2019, p. 149).

No que diz respeito à ideia de público, o $\mathrm{HQ}$ parece se aproximar da noção de público "como compartilhamento - como mundo comum" e da história como "uma forma específica - uma dentre outras com as quais pretende conviver e conversar como entre iguais e diferentes num mundo comum" distante de oposições entre "história pública versus história acadêmica" (SCHITTINO, 2016, p. 45-46). Apesar de alguns momentos de algum protagonismo do público, o formato foi "essencialmente unidirecional" (FRISCH, 2016, p. 59). Dito isso, vejamos a Tabela 1.

14 O tempo médio foi de 100 minutos. A atividade mais rápida durou 58 minutos, mas houve um debate com duração de 2 horas e 51 minutos e uma entrevista com duração de 2 horas e 20 minutos. Consideramos pouco provável que um público não acadêmico e/ou especializado tenha um corpo e uma mente com disciplina para manter a atenção em atividades online com essa duração. 
TABELA 1 - "Mitos da Ditadura" versus Pesquisa acadêmica15

\section{MITOS DA DITADURA COMENTÁRIO HISTORIOGRÁFICO}

1. Golpe e ditadura foram obras exclusivas dos militares

Na entrevista "Mitos da ditadura - usos politicos do passado II" (https://www.youtube.com/watch?v=7_aXGlnsTAk, 15'39"), Marcos Napolitano destacou que o golpe foi civil e militar e o regime foi militar. Para ele, compreender que o processo decisório foi militar não implica desconsiderar o protagonismo de civis que, inclusive, foram beneficiários de muitas políticas, especialmente, econômicas. Houve conflitos e muito apoio das classes médias, embora a adesão tenha diminuido à medida que as políticas econômicas do regime impuseram "arrocho" e dificultavam o consumo, sobretudo, a partir de meados dos anos 1970. No debate "Mitos da ditadura: estudantes, imprensa e mulheres" (https://www.youtube.com/watch? $v=N n 7$ W7-LRN34\&t=556s , 21'16"), Ana Rita Duarte sublinhou uma mudança na historiografia com a compreensão da ditadura como construção social que não envolveu apenas um embate entre militares e esquerda, mas implicou também a adesão e a busca do consenso envolvendo amplos setores sociais. Isso possibilitou um deslocamento do olhar para o cotidiano das relações sociais incorporando, por exemplo, como noções de gênero foram construídas/disputadas/mobilizadas nas instituições, nas políticas públicas, nas politicas educacionais e nos modelos de comportamento que atravessaram a ditadura. Na mesma ocasião, Sônia Meneses (51'17") sublinhou a trajetória de vários órgãos de imprensa no Brasil que apoiaram - golpe e a ditadura, mas construíram outra memória reivindicando um lugar de oposição. Ela selecionou o caso da Folha de S. Paulo que conseguiu reverter a memória do apoio à ditadura em algo positivo para a sua história realçando seu papel na transição democrática. Não nega o apoio, mas produz uma memória construída a partir da abertura política em que se colocaram como um canal da democracia. Essa reconstrução memorialística é constante.

$\mathrm{Na}$ entrevista citada na linha acima, Napolitano argumentou que a brutalidade do regime não aconteceu por causa da pressão de militares da linha dura sobre militares moderados. É comum o argumento de que havia uma intenção cívica salvacionista em 1964 que se perdeu por causa da linha dura. O rumo inicial teria sido retomado através da abertura política. No entanto, o que havia, de fato, era um projeto amplo e orgânico de estruturação e perpetuação do poder

Ao participar do debate "Mitos da ditadura: esquerdas, militares e corrupção", João Roberto Martins Filho (https://www.youtube.com/watch?V=wHImEn3VcQI\&t=1158s,

3. Os militares foram os últimos a embarcar no golpe 3'33") defendeu que o envolvimento mais direto dos militares com a política golpista de 1964 data de, pelo menos, 1961 quando, após a renúncia do presidente Jânio Quadros, eles tentaram impedir a posse de João Goulart. Mas o objetivo fracassou. A partir de então, começou uma série de conspirações contra os governos civis, desaguando no Golpe de 1964, que teve os militares como principais articuladores.

Na mesma oportunidade, Martins Filho (4'51") demonstrou que os maiores problemas enfrentados pelo primeiro governo da ditadura iniciada em 1964 vieram dos quartéis,

4. Os militares respeitavam as hierarquias e a disciplina principalmente dos setores que queriam fazer uma "revolução permanente". Os oficiais de baixa patente tinham uma expectativa de participação ativa na condução do regime, o que precisava ser administrado pelos generais. Além disso, nos momentos de sucessão presidencial não existia consenso acerca do nome a ser indicado. Portanto, os militares tinham de lidar constantemente com a insubordinação interna.

\footnotetext{
15 A Tabela 1 é um ensaio de sintese a partir dos vídeos. Pelo limite de espaço do artigo, não analisamos nem indicamos bibliografia sobre os 20 mitos. Do mesmo modo, nem todos os "mitos" mapeados nos vídeos foram sintetizados na tabela, já que há inúmeros mitos "à esquerda e à direita" que não foram elencados, pari passu à existência de diversas construções memorialisticas que impactaram na agenda historiográfica, tal qual elabora o debatedor Marcos Napolitano. Há o risco de excessiva simplificação do que foi dito. Para quem tiver interesse em aprofundar os temas, o HQ e a tabela devem ser vistos como um convite para assistir lives temáticas, bem como para a leitura de trabalhos historiográficos, começando pelas publicações dos palestrantes, que podem ser mapeadas acessando o currículo lattes individual.
} 


\section{MITOS DA DITADURA COMENTÁRIO HISTORIOGRÁFICO}

\section{A esquerda era golpista e violenta}

\begin{tabular}{ll} 
& progressista à violência e ao medo, deslegitimando a ação e a pauta daqueles grupos. \\
\hline & Araújo (12'44") também afirmou que, naquele contexto, a classificação de terrorista \\
& aplicava-se às pessoas que aterrorizavam as massas, o que não era o caso das \\
6. A esquerda era & ações da luta armada brasileira. Rotular de terroristas as ações que os grupos arma- \\
terrorista & dos desenvolviam no País servia como argumento e justificativa para a prática do \\
& terrorismo de Estado, como aconteceu na Guerrilha do Araguaia.
\end{tabular}

Ainda de acordo com Araújo (14'58"), o número de mortos do Brasil é supostamente menor do que nos países vizinhos, mas não é só isso que mede a violência e a brutalidade do regime. Essa diferença pode ser explicada tanto pelas características e peculiaridades politicas do contexto e da cultura politica do país, quanto pelos critérios utilizados para contabilizar as vítimas. O total de 434 mortos e desaparecidos no Brasil não leva em conta o massacre dos povos indígenas, com, aproximadamente, oito mil mortos e desaparecidos, nem o aumento exponencial dos mortos vitimas de acidente de trabalho em função do abrandamento das leis de proteção aos trabalhadores e às trabalhadoras, como apontou Pedro Campos (21'20") - que também participou das discussões. Além disso, a população da periferia sofria com batidas policiais e tortura psicológica. Portanto, a violência não foi só física, mas institucional, simbólica e estrutural, não direcionada exclusivamente para organizações de esquerda e formas de engajamento político clássicas, como atuação em partidos e movimentos sociais.

Contribuindo com as discussões sobre "Mitos da ditadura: esquerdas, militares e corrupção", Pedro Henrique Pedreira Campos (26'16") argumentou que houve um aparelhamento do Estado por empresários, que levaram práticas do âmbito privado para dentro da estrutura organizacional, entre as quais, pagamento de propina, ex-

8. Não havia corrupção clusão da concorrência etc. A construção de grandes obras (Transamazônica, Ponte Rio-Niterói, usinas hidroelétricas), junto com a censura dos meios de comunicação, criaram e pavimentaram o ambiente para o aumento da corrupção. No debate "Mitos da ditadura: milagre econômico, futebol e propaganda" (https://www.youtube. com/watch? V=RycTBZVvizo\&t=1333s, 1 h oo' 50"), David Netto (UEM) frisou o papel do tempo presente em impulsionar para gerações mais novas pesquisas que discutam o mito/propaganda construida pela ditadura a respeito da ausência de corrupção.

No debate intitulado "Mitos da ditadura: milagre econômico, futebol e propaganda", Paulo Robilloti (https://www.youtube.com/watch?V=RycTBZVvi2o, 12'51") afirmou que os militares utilizavam uma estrutura prévia que forneceu os subsidios para o

9. Milagre econômico acelerado crescimento entre 1967 e 1970. Isso se deu através do aproveitamento da capacidade ociosa da indústria no periodo anterior, possibilitando uma ampliação da produção, sem investimentos em estrutura produtiva. Além disso, a distribuição de renda e o aumento dos salários do período não acompanharam o crescimento do Produto Interno Bruto, fazendo que com as desigualdades sociais se aprofundassem ainda mais.

Na mesma rodada de discussão, Livia Gonçalves Magalhães (8'15") informou que

10. A copa do mundo de 1970 ajudou a consolidar a ditadura os militares lançaram mão da vitória do Brasil na Copa do Mundo de 1970 enquanto elemento de propaganda associada e personificada na figura do general Emilio Garrastazu Médici. O objetivo era fortalecer a imagem do governo; o que não significa que o esporte tenha sido um objeto da ditadura, tampouco que existiu um projeto político do futebol como projeto de poder. 


\section{MITOS DA DITADURA COMENTÁRIO HISTORIOGRÁFICO}

Conforme Flávia Rios (https://www.youtube.com/watch?V=WCuwpmMlotc, 10'41") no debate "Mitos da ditadura: trabalhadores, LGBTs, luta armada, religiosos e negros" -, a democracia racial foi ressignificada e apropriada pelo Estado ditatorial como uma ferramenta ideológica de legitimação do regime tanto interna quanto externa11. Democracia Racial mente. No cenário interno, a população negra era, de algum modo, tratada como um problema de segurança pública. Por outro lado, no plano internacional, ativistas e intelectuais, como Abdias do Nascimento, tentaram denunciar o mito da democracia racial em outros países e foram cerceados através da atuação da embaixada. Além disso, ativistas que tentavam viajar para outros países tinham seus vistos negados.

Na oportunidade, Caroline Cubas (18'26"), uma das participantes do debate supracitado, ressaltou que a Igreja Católica é composta por um corpo bastante heterogêneo e isso refletiu na relação estabelecida com o regime, principalmente em

12. Freiras não participaram da oposição ao regime relação ao papel das freiras. Existia um discurso de que, em função do espaço que elas ocupam na Igreja Católica, não teriam nenhum envolvimento com questões políticas e muito menos com o movimento de oposição à ditadura. Elas não participavam diretamente em grupos de oposição, mas atuaram com muita frequência em ações contra o regime ditatorial. Em alguns casos, por destoarem das orientações e dogmas da instituição, foram associadas ao comunismo.

No mesmo debate, Marcelo Ridenti (30'56") trouxe uma abordagem sobre o suposto caráter golpista dos comunistas. De acordo com o pesquisador, os comunistas tinham um projeto de revolução nacional e democrática que buscava a ampliação de direitos para a maioria da população, mas não tinha como estratégia a ruptura e a violência. Na entrevista "Mitos da ditadura - usos políticos do passado II" ( https://www.youtube.com/watch?v=7_aXGlnsTAk, 25'30"), Rodrigo Patto Sá Motta argumentou que, em 1964, muita gente acreditava que existia uma ameaça comu-

13. Os comunistas foram a causa do golpe: o perigo vermelho nista. Havia um movimento autêntico, mas havia muitas autoridades manipulando os medos anticomunistas. Muitos sabiam que as organizações de esquerda não tinham, naquele contexto, força para tomar o poder e imprimir uma revolução no Brasil. Depois do golpe, alguns de seus lideres reconheceram que houve uma superestimação do comunismo. Foi o momento em que começaram a investir mais no discurso de combate à corrupção, como uma forma de equilibrar a legitimidade e justificar o prolongamento do regime, já que eles rapidamente desmantelaram as organizações de esquerda. Portanto, o que manteve o regime no periodo seguinte foram interesses corporativos e econômicos, sendo o anticomunismo "um fantasma para justificar a ditadura".

\section{A atuação de grupos armados de esquerda foi respon- sável pela instaura- ção do Al-5}

Ridenti (35'26") pontuou - no debate citado acima - que as manifestações de 1968, que estavam em sintonia com alguns eventos e um clima internacional, aconteceram principalmente no primeiro semestre daquele ano. Quando o Ato Institucional 5 (Al-5) entrou em vigor, em dezembro, as manifestações já haviam cessado. O Al-5 foi ostensivo e não preventivo. Esse mito ajudou a forjar a unidade das forças que apoiavam a ditadura contra o inimigo externo.

Na ocasião, Alejandra Luisa Magalhães Esteves (41'21") demonstrou que a luta do operariado acontecia para além das greves. Existiu um trabalho intenso de disputa da esfera sindical em relação à negociação com o Estado. Observa-se que recorrentemente diretorias se formavam tentando compor chapa. Entretanto, essas chapas não ganhavam e quando ganhavam não conseguiam tomar a posse.

A pesquisadora declarou (45'24"), ainda, que o sindicato era uma instância privilegiada que o Estado precisava controlar para o domínio da classe trabalhadora que se forjava em um novo momento do desenvolvimento nacional. O regime militar não era contra a existência dos sindicatos, os militares desejavam a existência de um sindicato que não questionasse os desmandos do regime. 


\section{MITOS DA DITADURA COMENTÁRIO HISTORIOGRÁFICO}

17. A população dissidente de gênero teve sua cidadania reconhecida

No mesmo debate, Kleber Simões (49'55") afirmou que havia uma associação entre homossexualidade e o comunismo, visto pelo Estado e por boa parte da sociedade como um fator de destruição da família. Homossexuais eram condenados como sujeitos desviantes. Além disso, existiam instrumentos de repressão à sexualidade baseados no "veto moral" como forma de regulação dos corpos. O aparato policial também atuava através da delegacia de jogos e de costumes que cuidava do controle dos corpos nas ruas com operações de higienização dos espaços urbanos. Isso permaneceu durante todo o periodo ditatorial e, no periodo final do regime, essa imagem ganhou um reforço significativo com a associação do HIV à homossexualidade. Ainda hoje a população dissidente de gênero luta para ter seus direitos consolidados.

Ao participar da entrevista "Mitos da ditadura - usos políticos do passado", Carlos Fico (https://www.youtube.com/watch?V=4ID_iOZB1KM, 01'49") argumentou que a

18. As esquerdas sairam vitoriosas nas disputas de memória sobre a ditadura esquerda saiu frustrada da Ditadura (Civil) Militar por conta da ausência de ruptura entre a ditadura e a democracia e por conta do não julgamento dos militares. Muitas pesquisas de opinião pública apontavam que as forças armadas tinham uma imagem positiva na sociedade brasileira. Nos anos de governos do Partido dos Trabalhadores (PT), medidas de justiça de transição foram executadas, dando a impressão da prevalência de uma versão heroica sobre a luta armada.

Segundo Angélica Muller (https://www.youtube.com/watch?V=Nn7W7=-LR34N\&t$\underline{6 s}, 14$ '52") - no debate "Mitos da ditadura: estudantes, imprensa e mulheres" -, Edson Luís de Lima Souto foi morto pela polícia militar em 1968. O estudante e o ano tornaram-se marcos da história. Tornou-se um mártir, um herói do movimento estudantil, embora não fosse um estudante engajado, tampouco liderança estudantil. Sua morte foi apropriada pelo movimento estudantil como símbolo da resistência à ditadura. Foi um mito forjado pelo movimento estudantil. Ao longo da ditadura, a data da sua morte foi utilizada como um evento importante para a construção de uma memória de lutas e de uma identidade de resistência da União Nacional dos Estudantes (UNE). É parte da luta da geração de 1968 em disputa com outras

19. Edson Luís mártir do movimento estudantil gerações para construção de uma narrativa sobre a ditadura. Setores da imprensa também buscaram se apropriar do evento passado para capitanear a luta contra a ditadura durante e depois da ditadura em uma operação de reconstrução memorialística da sua própria atuação. O "mito" atravessou conjunturas. Em 1992, esteve presente no Fora Collor; em 2013, ele apareceu como um dos elementos de aderência nas manifestações daquele ano; e em 2018 apareceu como uma das bandeiras nas manifestações em resposta ao assassinato de Marielle Franco. Os exemplos mostram uma apropriação do mito por diferentes setores para além do movimento estudantil. Por último, na oportunidade, Ana Rita (44'19") acrescentou o mito que generaliza e associa estudante com resistência. A historiadora considera necessária a pesquisa sobre estudantes de direita e estudantes não engajados no movimento estudantil durante a ditadura. 


\section{MITOS DA DITADURA COMENTÁRIO HISTORIOGRÁFICO}

20. A repressão só atingiu "subversivos" e se concentrou nas capitais, sobretudo do Eixo Rio São Paulo
No debate intitulado "Mitos da ditadura: A ditadura para além do eixo Rio-São Paulo" (https://www.youtube.com/watch?v=C_mM5eO6ESU), Alessandra Gasparotto (12'48") afirmou que a Ditadura foi ampla. A repressão teve largo alcance no Estado, de Norte a Sul do País, atingindo toda a sociedade e muitos civis sofreram com a violência ditatorial: a população do campo, indígenas, a população negra e periférica. No Rio Grande do Sul, por exemplo, a repressão teve amplo alcance, sobretudo pela localização geopolítica do estado e por ser uma rota de exilio com amplo trânsito de militantes. Por isso, 68 municipios da região passaram a ser áreas de segurança nacional, 21 deles só no Rio Grande do Sul. Essas cidades passaram a sofrer um controle muito mais intenso. Ampliando o debate, Airton de Farias (28'54"), discorreu sobre a atuação da Ação Libertadora Nacional (ALN) e do Partido Comunista Brasileiro Revolucionário (PCBR) no Ceará questionando o mito da luta armada restrita ao Sudeste. Os arquivos do Serviço Nacional de Informações (SNI) e as fontes jornalisticas evidenciam uma intensa ação destas organizações no estado. Uma dessas ações foi o "justiçamento" de um comerciante executado pela ALN. Essa experiência foi traumática para a esquerda cearense, ensejou uma disputa memorialistica e, ainda hoje, é alvo de controvérsias. Pedro Ernesto (33'19"), por sua vez, discutiu o papel das elites econômicas no Espírito Santo na construção de um imaginário positivo acerca da ditadura (civil) militar no estado. Essa memória se construiu em oposição à predominância econômica do café e na disputa pela condução das políticas econômicas da região. Já Thiago Mesquita (45'13") trouxe o contexto ditatorial no Pará abordando o discurso do desenvolvimentismo e do integracionismo na região. Apesar de esse discurso aparecer apontando elementos positivos, ele foi prejudicial, especialmente, pelo impacto causado na forma como as populações locais se relacionavam com o território, acuadas por causa da disputa de terras. O processo de integração foi extremamente nocivo.

Fonte: Quadro elaborado pelos autores com base na sintese dos vídeos (2020).

Focando na Tabela 1, em meio a uma profusão de pesquisas sobre a ditadura brasileira dificil de ser mapeada mesmo pelos especialistas em razão da quantidade e diversidade de problemas de pesquisa, objetos, abordagens e centros de produção, a sintese histórica é necessária. O esquema apresentado pode ajudar pesquisadoras e pesquisadores do tema mergulhados na hiperespecialização sem uma visão historiográfica mais ampla. Além disso, a sintese oferece às pessoas não especializadas no período uma visão panorâmica de alguns "mitos". Sem esquecer seu caráter de incompletude, deve ser vista como uma imagem dinâmica que merece ganhar novos contornos, conteúdos e desenhos por outras mãos, inclusive com as percepções dos professores e professoras da universidade e da educação básica no seu ofício cotidiano da aula como um texto (MATTOS, 2006, p. 7). ${ }^{16}$ Desse modo, pode servir como um painel simplificado para a formação ao mesmo tempo em que deve ser lido como um quadro a ser reconstruido.

Além de fornecer dados sobre o periodo, o esforço de síntese pode inspirar análises mais amplas desde o conceito de mito, até pesquisas que aprofundem/demonstrem a (des)construção de alguns mitos em diferentes locais e fases da ditadura. Elaboramos a tabela com a intenção de que ela possa servir como ponto de partida para a construção de várias operações historiográficas:

16 "Professores e escritores de história contam uma história; ao texto escrito corresponde a aula. Ambos são autores; ambos fazem História (MATTOS, 2006, p. 7). 
acadêmica, escolar e de circulação ampla. ${ }^{17}$ No próximo tópico, oferecemos algumas sugestões.

\section{História em Quarentena e a pesquisa sobre a ditadura}

Na série "Mitos da ditadura", os convidados foram todos acadêmicos, sendo a maioria composta de historiadores e historiadoras. Além do instigante conteúdo - a parte sintetizada no tópico anterior é sugestiva, mas não expressa toda a riqueza do debate -, as falas nos impõem a escuta das entrelinhas, das sugestões e também dos não ditos. No caso do contexto da ditadura (civil) militar brasileira, lançamos problematizações que talvez sirvam para provocar novos estudos sobre o período e outros olhares para discussões já colocadas. Das múltiplas possibilidades oferecidas pelo HQ na série "Mitos da ditadura", focaremos nas categorias de raça, gênero e sexualidade.

A abordagem que envolveu o debate racial demonstrou haver pouca coisa produzida sobre o tema. Indicou caminhos proficuos para o aprofundamento de futuras pesquisas como as redes transnacionais nas quais se moviam os exilados em direção à Guiné Bissau, Moçambique, Portugal e Cuba, rearticulando o ativismo negro de socialistas e comunistas. Além disso, enfatizou como o mito da democracia racial foi operacionalizado pela ditadura para reprimir ativistas negros tanto no Brasil como no exterior. ${ }^{18}$ Isso quer dizer que, além de a população negra "representar um perigo interno à ordem pública", existia uma dimensão internacional na qual o País buscava se blindar de interferências de organizações internacionais ligadas à proteção dos direitos humanos, que se preocupavam com os processos de independência africanos, com o apartheid na África do Sul e com o movimento por direitos civis nos Estados Unidos (PIRES, 2018, p. 1061).

A necessidade imprescindivel de "colorir memórias" e "redefinir olhares" no que diz respeito à ditadura (civil) militar no Brasil (PIRES, 2015) vem acompanhada de uma ampla chave de leitura. Os trabalhos sobre a reconstituição da trajetória do Movimento Negro e de suas organizações (PEREIRA, 2013; FIGUEIREDO, 2016) e sobre as percepções dos agentes repressivos a respeito dos movimentos negros (KOSSLING, 2007) são fundamentais. Mas a chave da racialização precisa ser ampliada em análises sobre a branquitude. ${ }^{19} \mathrm{~A}$ imensa maioria dos altos oficiais militares era socialmente branca e é necessário perguntar quais as implicações deste lugar. Como algumas políticas públicas da ditadura impactaram brancos e negros?

A expansão das matrículas nas universidades públicas nos anos da ditadura manteve a instituição com alunos majoritariamente brancos por um longo periodo. O início do processo de enegrecimento do ensino superior público no Brasil ocorreu somente a partir de 2010 (COSTA, 2020).20 Pois bem: como era ser estudante universitário negro durante a ditadura? E professor universitário negro? O racismo impactou na demissão de professores negros como Milton

\footnotetext{
17 O conceito de operação historiográfica foi originalmente proposto por Michel de Certeau (1982), na década de 1970. Desde então, vem sendo debatido. Por muito tempo, a discussão girou em torno do processo de construção de conhecimento histórico acadêmico. Simplificando o debate, a operação historiográfica é entendida como um processo metodológico baseado em três pilares básicos: pesquisa empírica, debate teórico-metodológico (fase analítica); materialização (escrita da história). Em síntese, o conceito articula um lugar, práticas sociais e um texto. Fernando Penna (2013) propôs uma ampliação do conceito para pensar a produção dos professores e professoras de História quando preparam e executam uma aula. Partindo de uma noção ampla de texto - produto final da operação historiográfica -, o autor analisou o que chamou de operação historiográfica escolar, ou seja, aquela realizada cotidianamente por professoras e professores de História em sua prática docente. Ampliando ainda mais a discussão, Penna e Silva (2016, p. 198) sugerem pensar os múltiplos textos elaborados por profissionais da história para além da academia e do universo escolar, como museus, roteiros de filmes, firmas de consultoria, programas de televisão, internet etc. Seria o que Nicolazzi (2019, p. 211-212) denominou de regime historiográfico de circulação ampla, que se poderia aqui definir a partir do campo estabelecido pela história pública. Em cada um desses casos, a história é escrita, narrada e difundida segundo regras e protocolos distintos e, sobretudo, de acordo com demandas, modos de difusão e formas de recepção que são diferentes". Portanto, "cada historiografia seria pensada de acordo com a sua forma de inserção no espaço público, ou seja, segundo as suas finalidades específicas relativas ao seu destinatário imaginado no momento da produção" (PENNA; SILVA, 2016, p. 198).

18 Essas ideias foram desenvolvidas no debate "Mitos da ditadura: trabalhadores, LGBTs, luta armada, religiosos e negros" (80'44").

19 Sobre branquitude ver: HELMS, 1990; BENTO, 2002; SCHUCMAN, 2014; SOARES, 2020.

20 Apoiado em dados do IBGE, Gilberto Costa (2020) evidenciou que foi somente entre 2010 e 2019 que o número de alunas e alunos negros cresceu no ensino superior no Brasil. A taxa de crescimento foi de $400 \%$. No entanto, os negros chegaram a somente $38,15 \%$ do total de matriculados, percentual ainda abaixo de sua representatividade no conjunto da população (56\%). Em alguns cursos, como medicina, design gráfico, publicidade e propaganda, relações internacionais e engenharia química, não chegam a 30\%.
} 
Santos? ${ }^{21}$ A propósito, como o contexto de intolerância repressiva pós-Al-5 impactou os jovens negros das periferias? É necessário investigar outras formas de engajamento juvenil para além da inserção em organizações de esquerda e no movimento estudantil universitário. Para citar um exemplo, Risério (1981) nos instiga a pensar no impacto da soul music no comportamento de frações da juventude negra brasileira. A paranoia dos órgãos repressivos em torno do perigo da subversão da juventude tinha clivagens de classe, raça e região? A historiografia apresenta sinais e indícios afirmativos que merecem ser aprofundados. O delegado carioca Zonildo Castelo Branco criou um dicionário da subversão para orientar a repressão a partir da sua atuação no Rio de Janeiro, capital considerada mais permissiva no plano dos costumes e cosmopolita (HESSMAN, 2011). Já frações da censura nutriam insatisfação com um público universitário, intelectualizado e com condições de consumir produtos culturais potencialmente subversivos (MARCELINO, 2011). Esse público não era majoritariamente negro. De acordo com Cowan (2012, 2016), para a tecnocracia da Escola Superior de Guerra (ESG), o jovem que parecia alvo potencial da subversão comunista era branco, universitário e de classe média. Ainda segundo o autor, naquelas formulações produzidas na ESG, os jovens das camadas populares, majoritariamente negros, pareciam ser seduzidos pelo crime comum, como roubos e furtos.

Uma chave de leitura para a atuação da ESG é a permanência das teorias raciais, aportadas no Brasil a partir da década de 1870, operacionalizadas para categorizar os inimigos do Estado. Segundo Pires (2018, p. 1063), no Rio de Janeiro, a população negra do período vivia assombrada por "'blitz', prisões arbitrárias, invasões a domicilio, expropriação de lugares de moradia (remoções), torturas físicas e psicológicas, além do convivio com a ameaça latente dos grupos de extermínio". Vera Batista (2003, p. 84) demonstrou como o aparelho policial e os operadores jurídicos criminalizavam o uso de drogas por jovens pobres negros cariocas sugerindo um trato diferenciado em relação a jovens oriundos de familias de classe média. Esses eram vistos como consumidores, aplicando-se o estereótipo médico. Por outro lado, os jovens pobres - que no Brasil têm sido majoritariamente negros - eram vistos como traficantes, portanto, criminalmente estereotipados.

Documentos da repressão provam uma produção sistemática de papéis secretos de frações das comunidades de informação e segurança, que se diziam preocupadas com o comportamento juvenil. Relatórios das forças repressivas descrevem a vigilância em torno do uso de drogas na universidade, frequentada majoritariamente por jovens brancos. É preciso investigar se, ao contrário do que ocorria nas periferias, houve invasões frequentes em universidades motivadas pela agenda das drogas. A ampliação de estudos impulsionada pela Comissão Nacional da Verdade e pelas Comissões de Memória e Verdade das Universidades, com a descoberta de acervos repressivos fomentando novas abordagens ajudarão a investigar essa questão. A densa pesquisa de Motta (2014) sobre "Universidades e regime militar" contribui para o debate.

Até o momento, os indícios apontam que não era comum invasões em universidades motivadas pela repressão às drogas. Diferente do que foi disseminado nos documentos e veiculado publicamente, as frações de extrema direita militar também não tinham provas de uma suposta apropriação pelas organizações de esquerda revolucionária da difusão das drogas como estratégia revolucionária (LIMA, 2017; BRITO, 2021). Os exemplos nos permitem relativizar a força da pauta moral como combustivel para alimentar uma repressão ostensiva a jovens socialmente brancos das camadas médias urbanas. Um estudo centrado na racialização tanto das forças militares, quanto das juventudes certamente nos ajudaria a aprofundar as reflexões aqui propostas e investigar as diferentes sensações e experiências de ser jovem (branco e negro) durante a ditadura. A historiografia precisa dar visibilidade a essa pluralidade de representações, comportamentos e vivências.

${ }_{21}$ Na pesquisa em andamento sobre a trajetória de Milton Santos, Bruno Moreira (2020) oferece alguns elementos. 
Além da chave da racialização das relações sociais, o conceito de gênero mostra um potencial fecundo para a historiografia sobre a ditadura. Seu uso tem sido mobilizado principalmente quando investigamos as experiências de mulheres - quase sempre pensadas como femininas ${ }^{22}$ - e/ou de masculinidades e sexualidades dissidentes. ${ }^{23}$ Evidente que há estudos importantíssimos no campo. É fundamental o debate sobre a participação das mulheres na política, seja em apoio ou na resistência ao regime (CORDEIRO, 2009; RIDENTI, 1990; CUNHA, 2002; JOFFILY, 2009; REIS, 2015). E não se esgotam. Há grupos - como a Federação Brasileira pelo Progresso Feminino (FBPF), organização feminista dirigida por Bertha Lutz - que ainda não foram investigados. A FBPF é mais conhecida pela sua importância para os movimentos feministas no Brasil na primeira metade do século XX. Ainda não se investigou o papel que ela exerceu no apoio ao golpe e à ditadura. Logo após o golpe no dia 31 de março de 1964, Berta Lutz e Zuleika Lintz, respectivamente presidenta e vice-presidenta da instituição, enviaram telegramas para militares e civis golpistas. Na ocasião, em nome da FBPF, congratularam as autoridades por supostamente terem acabado com a crise que "infelicitava" o País e pela suposta restituição da democracia, ao mesmo tempo em que se pautaram demandas feministas relevantes, como o direito de as mulheres prestarem concurso para o Banco do Brasil e para juizas (ALVES, 2020, p. 152-154).

$O$ investimento em pesquisas sobre a FBPF durante a ditadura contribuiria, entre outras coisas, para ampliar os olhares acerca da história do feminismo no Brasil, sobretudo aqueles desenvolvidos a partir da década de 1970. Existe uma memória, comumente ratificada pela historiografia, que pensa os movimentos feministas no período como exclusivamente de esquerda. As experiências da FBPF parecem ser uma interrogação instigante que ainda não foi explorada, além de talvez pôr em xeque a dicotomia - também muito frequente - que divide a atuação politica das mulheres no periodo em dois grupos: conservadoras (que apoiaram a ditadura) e revolucionárias (que resistiram à ditadura). Seria possivel pensar uma organização feminista como a FBPF dentro desse binarismo? Os indícios parecem dizer que não.

Ademais, é importante destacar quão importantes são as pesquisas sobre gênero, moral e sexualidade no tempo da ditadura. Quais noções de masculino e feminino foram mobilizadas no discurso oficial do regime? Duarte (2011) e Langland (2008) ressaltam as profundas disputas em torno do gênero. Os trabalhos de Cowan (2012, 2016) são referências obrigatórias para pensar em como as forças repressivas buscaram delimitar a subversão na dimensão moral e sexual. James Green (2012) problematizou a masculinidade no interior de uma organização de esquerda armada. O relatório final da Comissão Nacional da Verdade (2014) contém um capítulo sobre a perseguição aos dissidentes eróticos. O livro organizado por Green e Quinalha (2015) apresenta um rico painel com diversos autores que vêm pesquisando o tema. Na sua tese de doutorado, Quinalha (2017) investiga a política sexual da ditadura. Brito (2019, 2020) demonstra a politização do sexo por frações militares para desqualificar sujeitos oposicionistas. Outras pesquisas em andamento ilustram o desenvolvimento da potência da abordagem. ${ }^{24}$

Estes são apenas alguns exemplos instigantes e não dão conta da diversidade de pesquisas produzidas nos 82 (oitenta e dois) Programas de Pós-Graduação em História no Brasil. ${ }^{25}$ Um

\footnotetext{
22 Hoje, dado o desenvolvimento do conceito de gênero, o masculino e o feminino não são - ou não deveriam ser - entendidos como caracteristicas naturais de homens e mulheres, respectivamente. A própria ideia que define o ser homem ou mulher é construida historicamente. 23 Por razões de espaço, destacamos alguns dossiês mais recentes que reúnem alguns artigos sobre a questão durante a ditadura: "Quando Clio encontra as 'sexualidades disparatadas'". Dossiê da Revista Esboços: Histórias globais (2016). Disponivel em: https://periodicos.ufsc br/index.php/esbocos/issue/view/2420/showToc. Acesso em: 20 ago. 2020.; "Lutas feministas e LGBTQ+ pela democracia no Brasil". Dossiê da Revista Anos 90 (2019). Disponivel em: https://seer.ufrgs.br/anosgo/issue/view/3659/showToc. Acesso em: 20 ago. 2020

24 Além dos trabalhos desenvolvidos por alguns participantes do HQ, mencionamos algumas pesquisas promissoras, como a de Caio Barbosa a respeito do projeto do IPES para a juventude brasileira, a de Raian Souza sobre perseguição a militares homossexuais e as pesquisas do Grupo de Pesquisas e Estudos em História e Gênero (GPEHG), da Universidade Federal do Ceará (UFCE).

25 Os cursos estão assim distribuidos: mestrado acadêmico - 26; Doutorado Acadêmico - 44; Mestrado - o9: Doutorado Profissional - 03. Disponível em https://sucupira.capes.gov.br/sucupira/public/consultas/coleta/programa/quantitativos/quantitativoAreaConhecimento.jsfijsessionid=QWheQgIPvYzwEgqBJvak6+Hj.sucupira-208?areaAvaliacao=40. Acesso em: 23 mar. 2021.
} 
balanço bibliográfico está para ser feito. $\mathrm{OHQ}$ contou, inclusive, com uma semana intitulada "Além da moral e dos bons costumes", que abre perspectivas importantes para a historiografia, a exemplo de pensar a relação entre anticomunismo e conservadorismo, refletir sobre a regulação das sexualidades na sociedade brasileira através do prisma da longa duração e das conexões transnacionais, problematizar a recepção desses discursos por largos setores sociais e pensar na apropriação desse repertório moral como parte das estratégias de reprodução da ditadura.

Mas como dissemos, é preciso ir além quando mobilizamos o conceito de gênero como categoria de análise histórica. Raramente mobiliza-se a categoria quando estamos falando de masculinidades hegemônicas. Não são apenas as mulheres ou os homens cuja masculinidade destoa da normatividade que são generificadas. Todas as pessoas são atravessadas pelo gênero, seja ele normativo ou não. Grosso modo, o conceito de gênero propõe a desnaturalização das diferenças sexuais apontando para o fato de que as categorias binárias homem-mulher, masculino-feminino, são construções culturais. Em outras palavras, a maioria das caraterísticas mobilizadas para definir o "ser homem" ou o "ser mulher" não são biológicas, mas historicamente construídas. Tanto é assim que mudam e apresentam diferenças substanciais a depender do tempo e/ou da cultura em que os sujeitos estão inseridos (TILLY, 1994: VARIKAS, 1994; MORANT, 1995; SCOTT, 1995; LUGONES, 2014; BUTLER, 2016).

A não racialização da branquitude e a não generificação de homens cisgênero que performam uma masculinidade normatizada nos remetem ao "paradigma do Outro" desenvolvido por Sueli Carneiro. A filósofa demonstra que o "Outro", leia-se, sujeitos subalternizados, é sempre nomeado; ao passo que o "Eu hegemônico", não (CARNEIRO, 2005). Se o "eu hegemônico" não é nomeado, ele se esconde na fumaça da universalidade. Os discursos dos homens brancos heteronormativos geralmente são pensados como universais, portanto livres de demarcadores. É fundamental apontar que o "eu hegemônico" também ocupa lugares sociais de gênero, raça e sexualidade. Todavia, a racialização dos brancos e a generificação da masculinidade normativa ainda são caminhos pouco explorados quando pensamos as pesquisas históricas sobre a ditadura no Brasil. Não seria o caso de investir em sinteses sobre o que orientava estas masculinidades e quais as tensões decorrentes da relação com o "Outro"? Ao pensá-las, seria imprescindivel a reflexão sobre os imbricamentos de gênero, raça e sexualidade no "eu hegemônico". Avançar em análises desse tipo certamente nos ajudaria a entender melhor a complexidade das relações raciais, de gênero e sexualidade no período.

\section{Considerações finais}

Ao longo de vinte semanas desde o começo da quarentena, iniciada no Brasil em março de 2020, o projeto História em Quarentena se destacou por várias razões: pioneirismo, regularidade e produção significativa em termos quali e quantitativos. Autorreconhecido como uma prática de história pública, com a devida licença poética a Ginzburg e Poni (1989, p. 170), seu acervo pode ser lido como uma "jazida preciosa de matérias primas" a serem exploradas. A série "Mitos da ditadura" - o recorte analítico esboçado neste texto - oferece várias possibilidades de operações historiográficas. Esse potencial inspirou a sintese organizada na tabela construida com vinte mitos envolvendo abordagens sobre a ditadura, instituições, sujeitos, experiências, escalas etc. Outros mitos estão presentes na série. Indicamos alguns desses potenciais. Esperamos que outros "olhos de ver" permitam florescer um sem-número de pesquisas. A historiografia e os dilemas contemporâneos exigem.

O HQ se apresenta também como um laboratório para se discutir a história pública no Brasil, especialmente, o engajamento em torno da difusão do conhecimento crítico produzido pela oficina da História neste boom de ocupação virtual amplificado pela pandemia. Em que pese a relevância da transmissão e a disponibilização online do $H Q$, a dinâmica dos meios digitais, a maneira e a velocidade de circulação das informações na internet impõem uma série de reflexões sobre a 
necessidade de dominar a linguagem e os códigos das plataformas virtuais, sobretudo quando se propõe divulgar conhecimento histórico para um público amplo a partir delas - iniciativa que se torna fundamental quando pensamos a importância de lidar com o avanço da apologia à ditadura (civil) militar è produção de fakenews e negacionismos.

A qualidade técnica na edição do material é um elemento que não deve ser desprezado, justamente porque impacta na possibilidade de atrair ou não um público diverso e mantê-lo atento ao conteúdo. De acordo com o historiador e músico Fabrício Mota (2020), em uma live da Rede de Historiadores e Historiadoras Negras transmitida no Instagram @historiadorxsnegrxs, muitos instrumentistas têm se especializado em trilhas para o Youtube com o objetivo de prender a atenção do internauta em um tempo acelerado em meio à overdose de estímulos visuais e de informação virtual. A observação de Mota é apenas um indício que nos ajuda a pensar o mercado digital e a profissionalização deste nicho para atrair a atenção do público pelo máximo de tempo possivel. As modalidades atuais de impulsionamento pago pelo Instagram e pelo Facebook indicam que, nesta era de informação acelerada, não é fácil extrapolar as bolhas e fazer a mensagem circular, ter curtidas, tampouco garantir visualização de vídeos por, pelo menos, 15 segundos. Há, inclusive, um mercado de especialistas treinados em planejar e gerenciar as técnicas de impulsionamento pago nas redes sociais. Ao mesmo tempo, sugerem que "a internet não é terra de ninguém". Não basta ter Wi-Fi, dados móveis, ideias e smartphone para produzir e disseminar conteúdo com o mesmo potencial de circulação. Há dimensões do imaginário, do contexto, do universo das emoções e das sensibilidades, do alfabeto da comunicação do e no mundo digital que devem ser acessadas para alimentar a atenção do público que navega online. Talvez isso ajude a explicar as razões pelas quais alguns videos crus e sem investimento técnico na edição viralizem enquanto outros não, mesmo aqueles superproduzidos tecnicamente.

Esses elementos podem nos ajudar a entender a adesão ou não de um público mais amplo ao projeto do $\mathrm{HQ}$, que apresentou vídeos crus e sem edição e alguns com duração que extrapolou duas horas. Longe de apontar "erros" do projeto, nosso objetivo é pautar algumas questões percebidas nesta época de produção de conteúdo digital para divulgação científica e sua relação com a história pública. Os elementos apresentados, de modo algum, são impositivos, até porque a experiência não teve a ambição de atrair uma grande quantidade de pessoas. Também não perdemos a dimensão de que o projeto foi construido no calor do contexto e da experiência e sem recursos para investir em técnicas que favorecessem uma produção mais profissionalizada. O próprio site foi custeado com "vaquinha online". ${ }^{26}$ A intenção é apenas demonstrar alguns dos elementos que trazem implicações à taxa de adesão, fatores que são operacionalizados por quem, muitas vezes, profissionalmente divulga conteúdos diversos nas plataformas digitais, inclusive negacionistas.

Em outra dimensão, como potencializar acervos virtuais como o HQ? No momento de conclusão deste texto, as visualizações a partir do canal do Youtube não parecem ter se ampliado significativamente para além daquelas construídas no calor da experiência - seja em tempo real, seja noutro turno ou dia. Isso sugere um arquivo de alta qualidade, mas pouco potencializado. $O$ indicio reforça a ideia de que a divulgação deve ser pensada também após a experiência imediata. Talvez atento a isso, o projeto HQ compartilhou os videos pelo Facebook como marco comemorativo do seu primeiro aniversário.

Uma pergunta mais ampla é: como circular o conhecimento histórico produzido nas redes, especialmente em projetos não amparados por financiamento? Não temos respostas, mas um caminho que parece promissor é alimentar o legítimo esforço de produção de conteúdo pela comunidade de historiadores sem perder de vista a necessidade de uma "curadoria" virtual 
que selecione, divulgue e potencialize o que já existe evitando uma "overdose de história online" dispersa em um mundo virtual já fragmentado. A produção de artigos acadêmicos - estilo balanço bibliográfico - mapeando essa produção virtual tomando o vídeo-debate como fonte documental pode ser um passo interessante.

O HQ é uma prática que reitera a conexão entre uma das modalidades da história pública com a história acadêmica. Por outro lado, são perceptiveis diferenças em como as narrativas sobre o passado se constroem quando se trata de uma exposição oral online. Na série "Mitos da ditadura", os expositores construiram suas narrativas sem ler textos, caracteristica comum em eventos acadêmicos. Falaram para um público escutar. Nos mesmos formatos, a historiadora ou o historiador se preocupa com a exatidão, o rigor, a crítica - amparado em procedimentos éticos e protocolos metódicos. Há complexidade nos dois casos, mas a escrita acadêmica obedece a regras distintas da exposição oral, sendo que a citação é uma delas. Mas é possivel - e foi comum no $H Q$ - exposições orais sem citações de autores do campo historiográfico. No vídeo de avaliação do projeto, o problema da citação emergiu e um dos debatedores sublinhou essa questão. Em uma impressão panorâmica não meticulosamente investigada - que combina a memória do lugar de público com a análise da série em tela - não nos parece ter havido excessos de citação. Muito pelo contrário. É necessário reunir um formato mais leve com a necessidade de explicitarmos publicamente o método de trabalho, os protocolos de pesquisa, os passos da investigação em relação ao objeto, a dimensão provisória da verdade, a busca da objetividade e o diálogo com autores como algo estrutural do conhecimento acadêmico.

Quando apresentada e/ou construidajunto com um público amplo, a pesquisa histórica não significa uma opinião entre tantas. Torna-se fundamental, portanto, deixar muito evidente as diferenças entre interpretação e pesquisa científica (seja ela feita por historiadores e historiadoras, profissionais ou não). Como fazer isso de forma leve e didática em espaços virtuais? Citar autores não seria uma demonstração de que o diálogo com os pares é um dos elementos essenciais na produção do conhecimento acadêmico? Não seria uma maneira de demonstração prática do rigor que envolve a nossa produção? Seja lá quais respostas o debate suscite, caso o exercicio de sintese estimule outras reflexões sobre história pública a partir do amplo acervo do $\mathrm{HQ}$ como de outros acervos virtuais, nosso objetivo já foi atingido.

\section{Referências}

ALMEIDA, Juniele Rabêlo de. Práticas de história pública: O movimento social e o trabalho de história oral. In: MAUAD, Ana Maria; ALMEIDA, Juniele Rabelo de; SANTHIAGO, Ricardo (org.). História Pública no Brasil: sentidos e itinerários. São Paulo: Letra e Voz, 2016. p. 47-55.

ALVES, Iracélli da Cruz. Feminismo entre ondas: mulheres, PCB e política no Brasil. 2020. Tese (Doutorado em História) - Instituto de História, Universidade Federal Fluminense, Niterói, 2020.

ANPUH EM PROSA: Divulgação científica e direito à História. Debatedores: Cristina Meneguello; Bruno Leal. Mediação: Márcia Motta; Benito Schmidt. [S. I.]: Anpuh-Brasil, 16/07/2020. (1h 40min 59 s), son., color. Disponivel em: https://www.youtube.com/watch?$\mathrm{v}=1 \mathrm{~B} 8 X 70$ AdTXM\&t=4279s. Acesso em: 30 ago. 2020.

BATISTA, Vera Malaguti. Dificeis ganhos fáceis: drogas e juventude pobre no Rio de Janeiro. Rio de Janeiro: Revan, 2003.

BENTO, Maria Aparecida Silva. Pactos narcísicos no racismo: Branquitude e poder nas organizações empresariais e no poder público. 2002. Tese (Doutorado em Psicologia Escolar e do Desenvolvimento Humano) - Instituto de Psicologia, Universidade de São Paulo, São Paulo, 2002.

BORGES, Vavy Pacheco. O que é História. São Paulo: Brasiliense, 2003.

BRITO, Antonio Mauricio Freitas. "Um verdadeiro bacanal, uma coisa estúpida": anticomunismo, sexualidade e juventude no tempo da ditadura. Anos 90, Porto Alegre, V. 26, p. 1-22, 2019.

BRITO, Antonio Mauricio Freitas. A droga da subversão: anticomunismo e juventude no tempo da ditadura. Revista Brasileira de História, São Paulo, n. 41, v. 86, p. 39-65, mar. 2021. https://doi.org/10.1590/ 1806-93472021v41n86-02.

BRITO, Antonio Mauricio Freitas. A subversão pelo sexo: Representações anticomunistas durante a ditadura no Brasil. Varia Historia, n. 36, v. 72, p. 859-888, out. 2020. https://doi.org/10.1590/0104-87752020000300010

BUTLER, Judith. Problemas de gênero: feminismo e subversão da identidade. 11. ed. Rio de Janeiro: Civilização Brasileira, 2016. 
CARNEIRO, Aparecida Sueli. A construção do Outro como não-ser como fundamento do ser. 2005. Tese (Doutorado em Educação) - Faculdade de Educação, Universidade de São Paulo, São Paulo, 2005

CERTEAU, Michel. A Escrita da História. Tradução de Maria Lourdes Menezes. Rio de Janeiro, Forense Universitária, 1982.

CHAUVEAU, Agnès; TÉTART, Philippe. Questões para a história do presente. Bauru: EDUSC, 1999

CIRO Barcelos Revela "Fiz Sexo Com Caetano Veloso e ex-mulher do cantor" Live Maria Zilda Bethlem. IS. I.]: Resumo da TV, 22/06/2020. (1h 02 min 24 s.), P\&B. Disponivel em: https://www.youtube.com/watch?$\mathrm{v}=$ PsXZG6iELk8\&t=2s. Acesso em: $30 \mathrm{ago} .2020$.

CONVERSAS histórias 3: História \& Música Negra - Parte 1. Convidado: Fabricio Mota; Mediação: Iracélli Alves. 28/08/2020. (55 min 58 s), color. Legendado. Disponivel em: https://www.instagram.com/tv/CEchDgkpgoL/?utm_ source=ig_web_copy_link. Acesso em: 30 ago. 2020.

CORDEIRO, Janaina Martins. Direitas em Movimento. A Campanha da Mulher pela Democracia e a ditadura no Brasil. Rio de Janeiro: FGV, 2009

COSTA, Gilberto. Cresce total de negros nas universidades, mas acesso é desigual. In: Agência Brasil. Brasilia, 20 nov. 2021. Disponivel em: https://agenciabrasil.ebc.com.br/ge$\mathrm{ral} /$ noticia/2020-11/cresce-total-de-negros-em-universidades-mas-acesso-e-desigual. Acesso em: 7 mar. 2021.

COWAN, Benjamin. "Why hasn't this teacher been shot?" Moral-sexual panic, the repressive right, and Brazil's National Security State. Hispanic American Historical Review, Durham, NC, v. 92, n. 3, p. 403-436, 2012.

COWAN, Benjamin. Securing sex: morality and repression in the making of cold war Brazil. North Carolina: The University of North Carolina Press, 2016.

CUNHA, Maria de Fátima da. A face feminina da militância clandestina de esquerda: Brasil anos 1960/70. 2002. Tese (Doutorado em História) - Instituto de Filosofia e Ciências Humanas, Universidade Estadual de Campinas, Campinas, 2002.

DUARTE, Ana Rita Fonteles. Homens e mulheres contra o inimigo: a mobilização do gênero pela ditadura militar brasileira (1964-1985). In: SIMPÓSIO NACIONAL DE HISTÓRIA, 26., 2011, São Paulo. Anais [...]. São Paulo: ANPUH, 2011. p. 1-14. Disponivel em: http://Www.snh2011.anpuh. org/resources/anais/14/1300279518_ARQUIVO_textocompletoanpuh.pdf. Acesso em: 1 mar. 2019.

EP. 31 - Como fazer a História Pública, por Icles Rodrigues. Expositor: Icles Rogrigues. 17/04/2020. (12min $46 \mathrm{~s}$ ), son., color. Disponivel em: https://www.youtube.com/ watch? $v=U$ bjGQQPH4_U\&t=78s. Acesso em: 30 ago. 2020.

FARIA, Daniel. Sob o signo da suspeita: as loucuras do poder ditatorial. Antiteses, Londrina, v. 8, n. 15, p. 221-240, nov. 2015.

FIGUEIRÊDO, Andersen Kubnhavn. Ativismo negro em Salvador no periodo da ditadura militar (1970-1980). Dissertação (Mestrado Profissional) - Programa de Pós-Graduação em História da África, da Diáspora e dos Povos Indigenas, Universidade Federal do Recôncavo da Bahia, Cachoeira, BA, 2016.
FRISCH, Michael. A história pública não é uma via de mão única ou De A Shared Authority à cozinha digital, e vice-versa. In: MAUAD, Ana Maria; ALMEIDA, Juniele Rabelo de; SANTHIAGO, Ricardo (org.). História Pública no Brasil: sentidos e itinerários. São Paulo: Letra e Voz, 2016. p. 57-69.

GINZBURG, Carlos; PONI, Carlo. O nome e o como: troca desigual e mercado historiográfico. In: GINZBURG, Carlos; CASTELNUOVO, Enrico; PONI, Carlo.A micro-história e outros Ensaios. Rio de Janeiro, Bertrand, 1989, p. 169-178

GREEN, James. "Who is the macho who wants to kill me?": male homosexuality, revolutionary masculinity, and the Brazilian armed struggle of the 1960 s and 70 s. Hispanic American Historical Review, Burham, NC, v. 92, n. 3, p. 437-469, ago. 2012.

GREEN, James; QUINALHA, Renan. Ditadura e homossexualidades: repressão, resistência e a busca da verdade. São Carlos: UFSCAR, 2015

HARTOG, François. Regimes de historicidade: presentismo e experiências do tempo. Belo Horizonte: Autêntica, 2014.

HELMS, Janet E. Black and white racial indentity: theory, research and practice. New York, Greedood Press: 1990.

HESSMANN, Dayane Rúbila Lobo. Cartilha da repressão: Os ensinamentos de um delegado sobre a Subversão e a Segurança Nacional (1974-1977). 2011. Dissertação (Mestrado em História) - Setor de Ciências Humanas, Letras e Artes, Universidade Federal do Paraná, Curitiba, 2011.

JOFFILY, Mariana. A diferença na igualdade: gênero e repressão política nas ditaduras militares do Brasil e da Argentina. Espaço Cultural, Cascavel, n. 21, p. 78-88, 2009.

KELLEY, Robert. Public History: Its Origins, Nature, and Prospects. The Public Historian, Califórnia, v. 1, n. 1, p. 16-28, Autumn 1978.

KOSSLING, Karin Sant'Anna. As lutas anti-racistas de afro-descendentes sob vigilância do DEOPS-SP (19651983). 2007. Dissertação (Mestrado em História) - Universidade de São Paulo, São Paulo, 2007.

LACOUTURE, Jean. A história imediata. In: LE GOFF, Jacques, CHARTIER, Roger; REVEL, Jaques (org.). A nova história. Coimbra: Almeida, 1978. p. 215-240.

LANGLAND, Victoria. Birth control pills and molotov cocktails. In: JOSEPH, Gilbert: SPENSER, Daniela. From the Cold: Latin America's new encounter with the Cold War. Durham, NC: Duke University Press, 2008. p. 308-349.

LIMA, Alexandre Siqueira. Primavera nos dentes: desbunde, anticomunismo e repressão na cidade em quadrinhos (1972-1973). 2017. Dissertação (Mestrado em História) - Universidade de Brasília, Brasília, 2017.

LUGONES, Maria. Rumo a um feminismo descolonial. Tradução de Juan Ricardo Aparicio e Mario Blaser. Estudos Feministas, Florianópolis, v. 22, n. 3. p. 935-952, set./dez. 2014.

MARCELINO, Douglas Attila. Subversivos e pornográficos: censura de livros e diversões públicas nos anos 1970. Rio de Janeiro: Arquivo Nacional do Ministério da Justiça, 2011. 
MATTOS, Ilmar Rohloff. "Mas não somente assim!" Leitores, autores, aulas como texto e o ensino-aprendizagem de História. Tempo, Niterói, v. 11, n. 21, p. 5-16, 2006. https://doi.org/10.1590/S1413-77042006000200002

MAUAD, Ana Maria; ALMEIDA, Juniele Rabêlo; SANTHIAGO, Ricardo. Introdução. In: MAUAD, Ana Maria; ALMEIDA, Juniele Rabêlo; SANTHIAGO, Ricardo (org.). História Pública no Brasil: sentidos e itinerários. São Paulo: Letra e Voz, 2016. p. 11-20.

MORAES, Luis Edmundo de Souza. O negacionismo e o problema da legitimidade da escrita sobre o passado. In: SIMPÓSIO NACIONAL DE HISTÓRIA - ANPUH, 26., São Paulo. Anais [...]. São Paulo: ANPUH, jul. 2011.

MORANT, Isabel. El sexo de la historia. In: MORANT, Isabel. Las Relaciones de Genero. Madri: Marcial Pons, 1995. p. 29-66.

MOREIRA, Bruno de Oliveira. Milton Santos e a ditadura civil-militar (1964-1985): prisão, exilio e memória. Exame de Qualificação de Doutorado - Faculdade de Filosofia e Ciências Humanas, Universidade federal da Bahia, 2020. Não publicado

MOTTA, Rodrigo Patto Sá. As universidades e o regime militar: cultura política brasileira e modernização autoritária. Rio de Janeiro: Zahar, 2014.

NAPOLITANO, Marcos. Combate ao negacionismo historiográfico confronta o obscurantismo que ameaça à democracia, diz historiador [Entrevista concedida a Jacqueline Boechat], Casa de Oswaldo Cruz, 9 mar. 2020. Disponivel em: http://Www.coc.fiocruz.br/index. $\mathrm{php} / \mathrm{en} / \mathrm{todas}-\mathrm{as}-$ noticias/1753-combate-ao-negacionismo-historiografico-visa-confrontar-o-obscurantismo-que-ameaca-a-democracia-diz-historiador.html\#. YFaYm1VKi1s. Acesso em: 25 mar. 2021.

NAPOLITANO, Marcos; JUNQUEIRA, Mary Anne. Negacionismos e Revisionismos: o conhecimento histórico sob ameaça. Sintese dos debates e posicionamentos surgidos no evento promovido pelo Departamento de História da FFLCH /USP - Universidade de São Paulo. São Paulo: USP, [ca. 2019] Disponivel em: https:// edisciplinas.usp.br/pluginfile.php/5207773/mod_folder/content/O/NAPOLITANO\%2C\%20Marcos\%3B\%20 JUNQUEIRA\%2C\%20Mary\%20Anne.\%20Como\%20historiadores $\% 20$ e $\% 20$ professores $\% 20$ devem $\% 20$ lidar $\% 20$ com\%20negacionismos\%20e\%20revisionismos.pdf?forcedownload=1. Acesso em: 20 mar. 2021.

NICOLAZZI, Fernando. Os historiadores e seus públicos: regimes historiográficos, recepção da história e história pública. História Hoje, [S. I], v. 8, n. 15, p. 203-222, 2019.

PENNA, Fernando de Araújo; SILVA, Renata da Conceição Aquino da. As operações que tornam a história pública: a responsabilidade pelo mundo e o ensino de história. In: MAUAD, Ana Maria; ALMEIDA, Juniele Rabelo de; SANTHIAGO, Ricardo. (org.). História Pública no Brasil: sentidos e itinerários. 1. ed. São Paulo: Letra e Voz, 2016. p. 195-205.

SEMANA 18: Mitos da ditadura - usos políticos do passado I Entrevista com Carlos Fico. Entrevistado: Carlos Fico. Entrevistadores: Carlos Trinidad, Lucas Pedretti, Mélanie Toulhoat, Natália Guerellus e Paulo Cesar Gomes. [S. I.]: História em Quarentena, 20/09/2020. (58min 37s.), son., color. Disponivel em: https://www.youtube. com/watch?V=4ID_iOZB1KM. Acesso em: 28 ago. 2020.
SEMANA 19: Mitos da ditadura - usos políticos do passado II | Marcos Napolitano e Rodrigo Patto. Entrevistados: Marcos Napolitano (Usp) e Rodrigo Patto (Ufmg). Mediação: Mélanie Toulhoat. [S. I.]: História em Quarentena, 30/09/2020. (2h 20min 04s), son., color. Disponivel em: https://www.youtube.com/watch?v=7_aXGInsTAk\&t=2643s. Acesso em: 28 ago. 2020.

SEMANA 18: "Mitos da ditadura: trabalhadores, LGBTs, luta armada, religiosos e negros" | Debate. Participantes: Alejandra Estevez (Uff); Caroline Cubas (Udesc); Flavia Rios (Uff); Kleber Simões (Ufba); Marcelo Ridenti (Unicamp). Mediação: Paulo César Gomes e Pedro Russo. [S. I.]: História em Quarentena, 25/07/2020. (2h 51 min 56 s), son., color. Disponivel em: https://www.youtube. com/watch?V=WCuwpmMlotc. Acesso em: 26 ago. 2020.

SEMANA 18: "Mitos da ditadura: esquerdas, militares e corrupção" | Debate. Participação: João Roberto Martins Filho (Ufscar), Maria Paula Araújo (Ufrj) e Pedro Campos (Ufrrj). Mediação: Lucas Pedretti. [S. I.]: História em Quarentena, 23/07/2020. (1h 26min 47 s), son., color. Disponivel em: https://www.youtube.com/ watch?V=wHImEn3VcQI\&t=38s. Acesso em: 20 ago. 2020.

SEMANA 18: "Mitos da ditadura: A ditadura para além do eixo Rio-São Paulo" | Debate. Participantes: Alessandra Gasparotto (Ufpel), Airton de Farias (Ifce), Pedro Fagundes (Ufes), Thiago Broni (Eap/Ufpa). Mediação: Paulo César Gomes. [S. I.]: História em Quarentena, 24/07/2020. (1h 59min 24 s.), son., color. Disponivel em: https://www.youtube.com/watch?v=C_mM5eO6ESU. Acesso em: 26 ago. 2020.

SEMANA 18: "Mitos da ditadura: estudantes, imprensa e mulheres". Produção de Participação de Angélica Muller (Uff), Ana Rita Fonteles (Ufc) e Sônia Meneses (Urca). Realização de Mediação Paulo César Gomes. IS. I.]: História em Quarentena, 26/07/2020. (1h 15min 35 s), son., color. Disponivel em: https://Www.youtube.com/ watch? $v=N n 7$ W7-LRN34\&t=6s. Acesso em: 20 ago. 2020.

SEMANA 18: "Mitos da ditadura: milagre econômico, futebol e propaganda". Participantes: Paulo Robilloti (Unicamp), Livia Magalhães (Uff), David Netto (Uem). Mediação: Lucas Pedretti. [S. I.]: História em Quarentena, 26/07/2020. (1h 37min 36 s), son., color. Disponivel em: https://Www.youtube.com/watch? V=RycTBZVvizo. Acesso em: 28 ago. 2020.

SEMANA 20: "E a pandemia não acabou: encerramento do projeto História em Quarentena" | Debate. Participantes: Carlos Benitez Trinidad (Usc/Cham-Unl), Lucas Pedretti (lesp/Uerj), Mariana Meneses Muñoz (Cham-Unl), Mélanie Toulhoat (Iheal), Natália de Santanna Guerellus (Université Jean Moulin) e Paulo César Gomes (Nec/Uff). Mediação: Odilon Caldeira Neto. IS. I.]: História em Quarentena, 8/08/2020. Son., color. Disponivel em: https://www.youtube.com/watch? v=M5C3FsCxvH4\&t=20s. Acesso em: 30 ago. 2020.

PENNA, Fernando de Araújo. Ensino de história: operação historiográfica escolar. Rio de Janeiro. 2013. Tese (Doutorado em Educação) - Faculdade de Educação, Universidade Federal do Rio de Janeiro, Rio de Janeiro, 2013.

PEREIRA, Amilcar Araújo. O mundo negro: relações raciais e a constituição do movimento negro contemporâneo no Brasil. Rio de Janeiro: FAPERJ/PALLAS, 2013. 
PIRES, Thula Rafaela de Oliveira. Colorindo memórias e redefinindo olhares: ditadura militar e racismo no rio de Janeiro. In: Portal Geledés. São Paulo, 17 dez. 2015. Disponivel em: https://www.geledes.org.br/colorindo-memorias-e-redefinindo-olhares-ditadura-militar-e-racismo-no-rio-de-janeiro. Acesso em: 23 mar. 2021.

PIRES, Thula Rafaela de Oliveira. Estruturas intocadas: racismo e ditadura no Rio de Janeiro. Direito \& Práxis, Rio de Janeiro, v. 9, n. 2, p. 1054-1079, 2018

QUINALHA, Renan. Contra a moral e os bons costumes: a política sexual da ditadura brasileira (1964-1988). 2017. Tese (Doutorado em Relações Internacionais) - Universidade de São Paulo, São Paulo, SP, 2017

REIS, Débora Ataide. Memória(s) militante(s): Narrativas Autobiográficas e Imagens de Resistência em Derlei Catarina De Luca (1966-1973). 2015. Dissertação (Mestrado em História Social) - Programa de Pós-Graduação em História Social, UFBA, Salvador, 2015.

RIDENTI, Marcelo Siqueira. As mulheres na política brasileira: os anos de chumbo. Tempo Social, São Paulo, v. 2, n. 2, p. 113-128, jun./dez. 1990.

RISÉRIO, Antônio. Carnaval ljexá: notas sobre afoxés e blocos do novo carnaval afrobaiano. Salvador: Corrupio, 1981.

RODEGHERO, Carla. O comunismo e outros perigos: memórias sobre o medo entre católicos. História Oral, [S. I.], v. 10, n. 2, p. 91-112, jul./dez. 2007

ROUSSO, Henry. O arquivo ou o indício de uma falta. Estudos Históricos, Rio de Janeiro, v. 9, n. 17, 1996.

SANTHIAGO, Ricardo. Duas palavras, muitos significados: alguns comentários sobre a história pública no Brasil. In: MAUAD, Ana Maria; ALMEIDA, Juniele Rabelo de; SANTHIAGO, Ricardo (org.). História Pública no Brasil: sentidos e itinerários. São Paulo: Letra e Voz, 2016. p. 23-35.

SANTHIAGO, Ricardo. Servir bem para servir sempre? Técnica, mercado e o ensino de história pública. História Hoje, [S. I.], v. 8, n. 15, p. 135-157, 2019

SCHITTINO, Renata. O conceito de público e o compartilhamento da história. In: MAUAD, Ana Maria; ALMEIDA, Juniele Rabelo de; SANTHIAGO, Ricardo (org.). História Pública no Brasil: sentidos e itinerários. São Paulo: Letra e Voz, 2016. p. 37-45.

SCHUCMAN, Lia Vainer. Entre o encardido, o branco e o branquissimo: Branquitude, hierarquia e poder na cidade de São Paulo. São Paulo, SP: Annablume, 2014.

SCOTT, Joan. Gênero: uma categoria útil para a análise histórica. Educação \& Realidade, Porto Alegre, v. 20, p. 71-99, jul./dez. 1995.

SOARES, Orson. A bondade do branco: olhar da branquitude sobre a questão racial no filme Também somos irmãos. 2020. Dissertação (Mestrado em História) - Universidade Federal do Rio Grande do Sul, Porto Alegre, 2020.

TILLY, Louise A. Gênero, História das Mulheres e História Social. Cadernos Pagu, Campinas, n. 3, p. 29-62, 1994.

VARIKAS, Gênero, experiência e subjetividade: a propósito do desacordo Tilly-Scott. Cadernos Pagu, Campinas, n. 3, p. 63-84, 1994.
VERAS, Elias Ferreira; PEDRO, Joana Maria. Os silêncios de Clio: escrita da história e (in)visibilidade das homossexualidades no Brasil. Revista Tempo e Argumento, Florianópolis, v. 6, n. 13, p. 90-109, set./dez. 2014

\section{Antonio Mauricio Freitas Brito}

Doutor em História pela Universidade Federal da Bahia, (UFBA), em Salvador, BA, Brasil; professor do Departamento de História/Programa de Pós-Graduação em História Social da Universidade Federal da Bahia, (UFBA), em Salvador, BA, Brasil.

\section{Iracélli da Cruz Alves}

Doutora em História Social pela Universidade Federal Fluminense, (UFF), em Niterói, RJ, Brasil; professora do Instituto Federal de Educação, Ciência e Tecnologia da Bahia, (IFBA), em Ilhéus, BA, Brasil.

\section{Rafael Rosa da Rocha}

Doutor em História Social pela Universidade Federal da Bahia (UFBA), em Salvador, BA, Brasil; Técnico em Assuntos Educacionais do Instituto Federal de Educação, Ciência e Tecnologia Baiano, (IF Baiano), em Catu, BA, Brasil.

\section{Endereço para correspondência}

Antonio Mauricio Freitas Brito

Universidade Federal da Bahia

Rua Professor Aristides Novis, 197

Federação, 40210-630

Salvador, BA, Brasil

Iracélli da Cruz Alves

Instituto Federal de Educação, Ciência e Tecnologia da Bahia

Av. Dom João VI, n. 275A, apto. 2003

Brotas, 40285-000

Salvador, BA, Brasil

Rafael Rosa da Rocha

Instituto Federal de Educação, Ciência e Tecnologia Baiano

Rua Antônio José, 13A

Boa Vista, 48110-000

Catu, BA, Brasil

Os textos deste artigo foram revisados pela Poá Comunicação e submetidos para validação do(s) autor(es) antes da publicação. 